\title{
KEABSAHAN PERKAWINAN KULI KAWIN DI DESA PAMANUKAN HILIR KABUPATEN SUBANG DIHUBUNGKAN DENGAN UNDANG-UNDANG NOMOR 1 TAHUN 1974 TENTANG PERKAWINAN DAN HUKUM ISLAM
}

\author{
VALIDITY OF MARRIAGE KULI KAWIN AT DESA PAMANUKAN HILIR \\ KABUPATEN SUBANG ACCORDING TO RELIGIOUS LAW AND ACT \\ NUMBER 1 OF 1974 CONCERNING MARRIAGE
}

\author{
Hazar Kusmayanti ${ }^{1}$, Eidy Sandra2, Rijalullah Rahmatullah ${ }^{3}$ \\ ${ }^{1,2,3}$ Fakultas Hukum Universitas Padjadjaran Bandung \\ Email: hazarkusmayanti@unpad.ac.id
}

\begin{abstract}
In general, a man or woman needs to live together. Living together between a man and a woman has a very important impact on society, both on both sides and their descendants and other members of the community. Marriage in Indonesia always varies in shape. The kuli nikah in Desa Pamanukan Hilir, Kabupaten Subang, aims to justify the ex-wife who has been divorced three by her husband so that he can return to reconciliation. This paper wants to examine how the validity of marriages is married and how the legal consequences of the marriage. The results of the study show that kuli nikah occur in people's lives are declared invalid according to Article 2 paragraph (1) of Law Number 1 of 1974 concerning Marriage, as well as for the Islamic community, every marriage event must be registered according to the provisions of Article 5 paragraph (1) of Compilation Islamic law. The legal consequences of marriages of married laborers according to Islamic law are unlawful under Article 2 of the Compilation of Islamic Law for violating the purpose of marriage as mitssaqa ghalidzan, therefore marriage that is not valid according to religious law and belief results in illegality according to Article 2 paragraph (1) Law Number 1 of 1974 concerning Marriage.
\end{abstract}

Keywords: Marriage, kuli nikah, compilation islamic law

\section{Intisari}

Pada umumnya, seorang pria maupun seorang wanita timbul kebutuhan untuk hidup bersama. Hidup bersama antara seorang pria dan seorang wanita mempunyai akibat yang sangat penting dalam masyarakat, baik terhadap kedua belah pihak maupun keturunannya serta anggota masyarkat yang lainnya. Pelaksanaan perkawinan di Indonesia selalu bervariasi bentuknya. Perkawinan kuli kawin di Desa Pamanukan Hilir Kabupaten Subang bertujuan untuk menghalalkan mantan istri yang sudah ditalak 3 (tiga) oleh suaminya agar dapat kembali rujuk. Tulisan ini akan mengkaji mengenai bagaimana keabsahan perkawinan kuli kawin dan bagaimana akibat hukum dari perkawinan tersebut. Perkawinan kuli kawin yang terjadi di kehidupan masyarakat dinyatakan tidak sah menurut Pasal 2 ayat (1) Undang-Undang Nomor 1 Tahun 1974 tentang Perkawinan, serta bagi masyarakat Islam setiap peristiwa perkawinan harus 
dicatatkan berdasarkan ketentuan Pasal 5 ayat (1) Kompilasi Hukum Islam. Akibat hukum dari perkawinan kuli kawin menurut Hukum Islam adalah haram hukumnya berdasarkan Pasal 2 Kompilasi Hukum Islam karena melanggar tujuan perkawinan sebagai mitssaqa ghalidzan, oleh karena itu perkawinan yang tidak sah menurut hukum agama dan kepercayaannya maka mengakibatkan tidak sah juga menurut Pasal 2 ayat (1) Undang-Undang Nomor 1 Tahun 1974 tentang Perkawinan.

Katakunci: Pernikahan, kuli nikah, kompilasi hukum Islam.

\section{A. Pendahuluan}

Manusia menurut kodratnya diciptakan oleh Tuhan Yang Maha Esa dengan dua peranan yang harus dilakoni dalam kehidupan, yaitu sebagai makhluk individu dan sebagai makhluk sosial. Manusia dengan perannya sebagai makhluk sosial akan selalu hidup bersama dengan manusia lainnya di dalam suatu pergaulan hidup, baik untuk memenuhi kebutuhan jasmani maupun rohani. Hubungan tersebut dapat dibangun melalui hubungan antar lawan jenis yaitu melalui hubungan perkawinan.

Pada umumnya seorang pria maupun seorang wanita timbul kebutuhan untuk hidup bersama melalui ikatan perkawinan. Perkawinan merupakan salah satu peristiwa penting dalam kehidupan manusia. Allah telah menciptakan segala makhluk dalam bentuk berpasang-pasangan sebagaimana firman Allah yang terjemahannya sebagai berikut: "Dan segala sesuatu kami ciptakan berpasangpasangan" (Al-Qur'an surat adz-Dzaariyat ayat 49 ).

Perkawinan tidak hanya sekedar hubungan lahiriah saja, tetapi lebih dari itu perkawinan merupakan satu ikatan atau hubungan lahir batin antara seorang lakilaki dan seorang perempuan yang bertujuan untuk membentuk suatu keluarga yang bahagia dan kekal berdasarkan Ketuhanan Yang Maha Esa. ${ }^{1}$ Perkawinan dalam ajaran Islam mewajibkan umatnya untuk melakukan perkawinan secara bersih-ilahiyah, dimana perkawinan tersebut harus mengikuti aturan agama dan mengindahkan etika pergaulan sehingga mencapai keridhaan. Islam memandang seseorang dinyatakan telah siap melaksanakan perkawinan apabila telah dianggap cukup umur dan telah siap untuk menjalani kehidupan rumah tangga serta telah memiliki seseorang yang dicintai dan disayangi.

Al- Qur'an menetapkan perkawinan sebagai "mitssaqan ghalidzan" yang memiliki arti janji yang sangat kuat. Istilah ini mengisyaratkan bahwa perkawinan itu merupakan perjanjian serius antara mempelai pria (suami) dengan mempelai wanita (istri) sehingga perkawinan yang sudah dilakukan harus dipertahankan dan dipertanggung jawabkan kelangsungannya oleh yang menjalankannya.

Ajaran Islam pada dasarnya memungkinkan terjadinya talak (perceraian), tetapi Rasulullah S.A.W menjulukinya hal tersebut sebagai perbuatan yang halal yang di benci oleh Allah SWT. ${ }^{2}$ Rumah tangga yang sakinah selalu menjadi idaman setiap pasangan suami isteri. Ketenangan, ketentraman, cinta, kasih

${ }^{1}$ Sution Usman Adji, Kawin Lari dan Kawin Antar Agama, cet. 1, Yogyakarta: Liberty, 1989 , hlm.21

${ }^{2}$ Muhammad Amin Summa, “Hukum Keluarga Islam di Dunia Islam”, PT Raja Grafindo Persada, Jakarta, 2005, hlm.50

Suloh: Jurnal Fakultas Hukum Universitas Malikussaleh, Vol. 7, No. 2, April 2019, pp. 1 - 13 
sayang, kebahagiaan, kemandirian, kemampuan dan keamanan menjadi sederet harapan dalam hidup berumah tangga, namun tak jarang juga perkawinan diakhiri dengan perceraian. ${ }^{3}$

Perkawinan seperti yang telah dijelaskan di atas bahwa sah apabila dilakukan menurut hukum masing-masing agamanya dan kepercayaannya, hal ini dapat di pakai sebagai dasar hukum berlakunya Hukum Perkawinan Islam di Indonesia sebagai peraturan khusus di samping peraturan umum yang di atur dalam Undang-Undang Perkawinan untuk warga negara Indonesia yang beragama Islam, yang kebanyakan menganut ajaran dari mahzab Syafi'i. Dalam hubungan perkawinan antara suami istri itu terjadi perjanjian yang suci yaitu Miitsaaqan ghaliizhaan, perjanjian yang suci dan kokoh, membentuk keluarga yang bahagia kekal dan abadi (Al Qur'an Surah An Nisa: 21). Islam menganjurkan perkawinan, dengan diadakannya perkawinan maka telah terpenuhinya perintah agama dengan tujuan mendirikan rumah tangga yang sakinah, mawadah dah rahmah. ${ }^{4}$

Perceraian di Indonesia menurut hukum Islam yang telah dipositifkan dalam Pasal 38 dan Pasal 39 Undang-Undang Perkawinan yang telah dijabarkan dalam Peraturan Pemerintah Nomor 9 Tahun 1975 tentang Implementasi Hukum Perkawinan Nasional mencakup cerai talak yang perceraiannya diajukan oleh suami kepada pengadilan agama dan cerai gugat yang percerainnya di ajukan oleh isteri kepada pengadilan agama sedangkan perceraian menurut hukum agama selain hukum islam yaitu merupakan perceraian yang gugatan cerainya diajukan oleh dan atau inisiatif suami atau isteri kepada pengadilan negeri. ${ }^{5}$

Perceraian talak dalam hukum Islam merupakan perceraian yang diajukan oleh suami kepada istrinya dapat dijatuhkan sebanyak 3 (tiga) kali dan setelahnya tidak dapat rujuk kembali, sebelum menikah dan bercampur dengan orang lain.

Talak (yang dapat dirujuki) dua kali. Setelah itu boleh rujuk lagi dengan cara yang ma'ruf atau menceraikan dengan cara yang baik. Tidak halal bagi kamu mengambil kembali sesuatu dari yang telah kamu berikan kepada mereka, kecuali kalau keduanya khawatir tidak akan dapat menjalankan hukum-hukum Allah. Jika kamu khawatir bahwa keduanya (suami isteri) tidak dapat menjalankan hukum-hukum Allah, maka tidak ada dosa atas keduanya tentang bayaran yang diberikan oleh isteri untuk menebus dirinya. Itulah hukum-hukum Allah, maka janganlah kamu melanggarnya. Barangsiapa yang melanggar hukum-hukum Allah mereka itulah orang-orang yang zalim. (Terjemahan Al-Qur'an Surat Al-Baqarah Ayat 229).

Suami yang telah menjatuhkan talak satu atau dua kepada istrinya masih berhak untuk melakukan rujuk dengan istrinya, selama masih masa iddah, baik istri ridha maupun tidak ridha. Namun, jika talak tiga sudah jatuh maka suami tidak memiliki hak untuk rujuk kepada istrinya, sampai sang istri dinikahi oleh

\footnotetext{
${ }^{3}$ Luqman Haqani, "Prahara Rumah Tangga”, Pusaka Ulumuddin, Bandung, 2004, hlm 5.

${ }^{4}$ Sudarsono, Hukum Perkawinan Nasional, Rineka Cipta, Jakarta, 2010, hlm. 2.

5 Muhammad Syaifuddin, dkk, "Hukum Perceraian” cet. 2, Sinar Grafika : Jakarta, 2014,
} hlm. 19 
lelaki lain. Suami dan Istri dalam kondisi ini, sudah lepas hubungannya atau masing-masing sudah bebas dari ikatan perkawinan yang mereka sebelumnya jalani.

Kemudian jika si suami mentalaknya (sesudah talak yang kedua), maka perempuan itu tidak lagi halal baginya hingga dia kawin dengan suami yang lain. Kemudian jika suami yang lain itu menceraikannya, maka tidak ada dosa bagi keduanya (bekas suami pertama dan isteri) untuk kawin kembali jika keduanya berpendapat akan dapat menjalankan hukum-hukum Allah. Itulah hukum-hukum Allah, diterangkan-Nya kepada kaum yang (mau) mengetahui (Terjemahan Al-Qur'an Surat Al-Baqarah Ayat 230).

Fenomena yang terjadi di Desa Pamanukan Hilir Kabupaten Subang Jawa Barat terdapat perkawinan kuli kawin. Perkawinan kuli kawin dilakukan dengan maksud untuk menghalalkan mantan isteri yang telah di talak tiga sehingga dapat rujuk kembali dengan mantan suaminya. Perkawinan kuli kawin sendiri tidak memiliki pengaturan yang jelas baik menurut peraturan perundang-undangan yang berlaku di Indonesia.

Perkawinan kuli kawin ini masih dilakukan dengan tujuan untuk menghalalkan mantan isteri yang telah di talak 3 (tiga) oleh mantan suaminya, agar mantan suaminya ini dapat kembali menikahi mantan isterinya tersebut. Pelaksanaan kuli kawin ini dilakukan hanya dihadiri oleh beberapa orang saja, tanpa adanya walimah atau resepsi perkawinan.

Perkawinan kuli kawin ini tidak mengenal adanya pencatatan perkawinan dan hanya dilakukan dengan niat menceraikannya setelah melakukan hubungan suami isteri, bukan dengan niat yang mulia yaitu membentuk sebuah rumah tangga yang sakinah mawaddah dan rahmah. Faktanya umur perkawinan kuli kawin yang dilakukan hanya beberapa hari saja bahkan hanya untuk digauli setelah itu mereka bercerai dan laki-laki kedua itu mendapatkan upah dari pihak keluarga perempuan.

Perkawinan kuli kawin ini negara tidak tahu-menahu karena negara tidak mencatatkan pernikahan tersebut. bila terjadi sesuatu dari pernikahan kuli kawin ini, maka konsekuensi pelaksanaan hak dan pelaksanaan kewajiban itu tidak bisa diketahui. Bila dikembalikan pada hukum perkawinan Islam, maka selagi perkawinan telah dilakukan memenuhi syarat dan rukunnya, perkawinan itu adalah sah dan berhak atas ketentuan yang digariskan dalam hukum perkawinan Islam.

\section{B. Pembahasan}

Perkawinan merupakan ikatan suci antara seorang laki-laki dan perempuan yang mensahkan status hukum seseorang sebagai suami dan istri. Hal ini menyebabkan dihalalkannya seksual dengan tujuan membentuk suatu keluarga yang aman tentram, penuh kasih sayang serta saling menyantuni. Perkawinan merupakan suatu peristiwa yang sangat penting dalam kehidupan seseorang karena dapat mempengaruhi status orang tersebut. Oleh karena itu, perkawinan 
harus dilaksanakan menurut ketentuan-ketentuan yang berlaku sehingga dipandang sah menurut hukum positif.

Pasal 1 Undang-Undang Nomor 1 Tahun 1974 menyebutkan bahwa yang menjadi tujuan perkawinan sebagai suami istri adalah untuk membentuk keluarga (rumah tangga) yang bahagia dan kekal berdasarkan Ketuhanan Yang Maha Esa, selanjutnya dijelaskan bahwa untuk itu suami isteri perlu saling membantu dan melengkapi agar masing-masing dapat mengembangkan kepribadiannya membantu dan mencapai kesejahteraan spiritual dan material. ${ }^{6}$

Menurut Hukum Islam yang dimaksud dengan perkawinan ialah akad yang menghalalkan pergaulan dan membetasi hak dan kewajiban serta saling tolong menolong antara seorang laki-laki dan seorang perempuan yang antara keduanya bukan muhrim (Ta'rif ini disampaikan oleh Sulaiman Rasyid di dalam bukunya yang berjudul Figh : 348). Apabila ditinjau secara perinci pernikahan atau perkawinan adalah aqad yang bersifat luhur dan suci antara laki-laki dan perempuan yang menjadi sebab sahnya sebagai suami istri dan dihalalkannya hubungan seksual dengan tujuan mencapai keluarga yang penuh kebajikan dan saling menyantuni; keadaan seperti ini lazim disebut sakinah.

Menurut Hukum Perkawinan Islam terdapat beberapa unsur yakni: Orang yang mengikatkan diri di dalam pernikahan adalah laki-laki dan perempuan yang menurut Al-Qur'an terdapat beberapa kaidah dasar yang wajib dipatuhi. Sedangkan status antara laki-laki dan perempuan yang sudah melangsungkan akad nikah meningkat menjadi suami istri yang keduanya memilki hak dan kewajiban yang telah diatur di dalam Islam. Akad nikah akhirnya menghalalkan hubungan badan antara suami istri sesuai dengan ketentuan agama.

Pembentukan keluarga yang bahagia itu erat hubungannya dengan keturunan, dimana pemeliharaan anak dan pendidikan anak menjadi hak dan kewajiban orang tua, dengan demikian yang menjadi tujuan perkawinan menurut perundang-undangan adalah kebahagiaan untuk suami istri, untuk mendapatkan keturunan dan menegakan keagamaan dalam kesatuan keluarga yang bersifat parental (ke-orangtua-an). ${ }^{7}$

\section{Perkawinan Kuli Kawin Menurut Undnag-Undang Nomor 1 Tahun 1974}

Undang-Undang Nomor 1 Tahun 1974 tentang Perkawinan sebenarnya tidak membenarkan bahwa perkawinan dapat diakhiri dengan sewenang-wenang meskipun terdapat unsur perjanjian karena tidak sesuai dengan asas yang berlaku dalam Undang-Undang Nomor 1 Tahun 1974 tentang Perkawinan yaitu mempersulit perceraian. Sementara, perkawinan kuli kawin sifatnya tidak langgeng karena mengandung unsur perjanjian yang pada intinya menentukan batas waktu dari seorang pria dan wanita dalam melangsungkan perkawinan sehingga bertentangan dengan filosofi tujuan pernikahan.

Perkawinan dikatakan sah apabila telah memenuhi unsur dalam Pasal 2 ayat (1) Undang-Undang Nomor 1 Tahun 1974 yang menyebutkan: "Perkawinan

\footnotetext{
${ }^{6}$ Hilman Hadikusuma, Hukum Perkawinan Indonesia Menurut Undang-Undang, Hukum Adat, Hukum Agama, Bandung:Mandar Maju, hlm.21.

${ }^{7}$ ibid, hlm. 22
} 
adalah sah apabila dilakukan menurut hukum masing-masing agamanya dan kepercayaannya itu" selanjutnya, dalam Pasal 2 ayat (2) Undang-Undang Nomor 1 Tahun 1974 selanjutnya menyebutkan bahwa: "Tiap-tiap perkawinan dicatat menurut peraturan perundang-undangan yang berlaku."

Ada 2 (dua) pendapat tentang penafsiran Pasal 2 Undang-Undang Nomor 1 Tahun 1974, yaitu ${ }^{8}$ :

1. Ada kecenderungan dari beberapa sarjana hukum yang ingin memisahkan penafsiran Pasal 2 ayat (1) dengan Pasal 2 ayat (2), bahwa perkawinan sah apabila dilakukan menurut hukum masing-masing agama dan kepercayaan itu sedangkan pendaftaran adalah syarat administrasi saja dilakukan atau tidak, tidak merupakan suatu cacat atau lebih tegas lagi tidak menyebabkan tidak syahnya perkawinan tersebut;

2. Di lain pihak ada pula kecenderungan sarjana hukum yang menafsirkan Pasal 2 ayat (1) dan Pasal 2 ayat (2) bukan saja dari sudut juridis sematamata yaitu sahnya perkawinan, tetapi juga dikaitkan secara sosiologis yang menurut mereka Pasal 2 ayat (1) dan Pasal 2 ayat (2) itu tidak dapat dipisahkan sedemikian rupa tetapi dianggap merupakan rangkain kesatuan bagaikan benang dengan kulin dan jalin menjalin satu, apabila yang satu lepas maka yang lain berkurang kekuatannya bahkan hilang sama sekali.

Undang-Undang Nomor 1 Tahun 1974 tentang Perkawinan mensyaratkan untuk dilakukannya pencatatan perkawinan sebagai syarat diakuinya perkawinan menurut negara. Kewajiban untuk melakukan pencatatan ini juga ditegaskan dalam Pasal 34 Undang-Undang Nomor 23 Tahun 2006 tentang Administrasi Kependudukan yang menyatakan bahwa setiap perkawinan yang sah berdasarkan ketentuan peraturan perundang-undangan wajib dilaporkan kepada instansi pelaksana yang berwenang paling lambat 60 hari sejak tanggal perkawinan untuk kemudian dicatatkan pada register akta perkawinan dan diterbitkan kutipan akta perkawinan. Bahkan orang yang melampaui batas pelaporan dalam mendaftarkan perkawinannya bisa dikenakan sanksi administratif berupa denda.

Pencatatan perkawinan walaupun hanya berupa tindakan administratif saja bukan sebagai penentu sah atau tidaknya suatu perkawinan namun pencatatan perkawinan menjadi hal yang penting untuk memberikan kepastian hukum terkait status dan kedudukan suatu perkawinan yang nantinya juga akan berpengaruh pada akibat hukum yang ditimbulkan dari perkawinan tersebut.

Undang-Undang Nomor 1 Tahun 1974 tentang Perkawinan dengan demikian memberikan pandangan bahwa perkawinan yang dilakukan Rukiyat dan Sumiyati serta perkawinan sebagaimana penulis teliti adalah tidak sah berdasarkan ketentuan penafsiran dalam Pasal 2 Undang-Undang Nomor 1 Tahun 1974 tentang Perkawinan. Menurut Mohd. Idris Ramulyo, yang menjelaskan bahwa Pasal 2 ayat (1) dan Pasal 2 ayat (2) bukan saja dari sudut juridis semata-mata yaitu sahnya perkawinan, tetapi juga dikaitkan secara sosiologis, Pasal 2 ayat (1) dan Pasal 2 ayat (2) itu tidak dapat dipisahkan sedemikian rupa tetapi dianggap merupakan rangkaian kesatuan yang harus dilaksanakan.

${ }^{8}$ M. Idris Ramulyo, Op.Cit, hlm. 92.

Suloh: Jurnal Fakultas Hukum Universitas Malikussaleh, Vol. 7, No. 2, April 2019, pp. 1 - 13 


\section{Perkawinan Kuli Menurut Hukum Islam}

Perkawinan yang dilaksanakan oleh kedua mempelai harus dilaksanakan secara Islam sesuai dengan ketentuan Pasal 4 Kompilasi Hukum Islam karena kedua mempelai baik Rukiyat dan Sumiyati menganut agama Islam. Dalam praktik perkawinan kuli kawin, perkawinan dilakukan secara sembunyi-sembunyi tanpa mendaftaran ke Kantor Urusan Agama setempat. Para pihak hanya melangsungkan perkawinan dibawah tangan, oleh karena itu perkawinan kuli kawin tidak diakui dan tidak memiliki akibat hukum sebagai perkawinan yang sah sebab selain tidak dicatatkan pada instansi yang berwenang, perkawinan ini juga merupakan perkawinan yang tidak sah hukumnya.

Pasal 2 Kompilasi Hukum Islam kemudian menjelaskan bahwa perkawinan menurut hukum Islam adalah pernikahan, yaitu akad yang sangat kuat atau mitssaqan ghalidzan untuk mentaati perintah Allah dan melaksanakannya merupakan ibadah. Istilah mitssaqan ghalidzan, dalam Al-Qur'an mengandung arti bahwa perkawinan itu merupakan perjanjian serius antara suami dengan istri dan harus dipertahankan dan dipertanggungjawabkan oleh yang menjalankannya.

Sahnya suatu perkawinan menurut hukum Islam harus memenuhi dua unsur, yaitu rukun dan syarat. Rukun adalah unsur yang melekat pada peristiwa atau perbuatan hukum, baik dari segi para subjek hukum maupun objek hukum yang merupakan bagan dari peristiwa atau perbuatan hukum ketika peristiwa tersebut berlangsung. Rukun menentukan sah atau tidaknya suatu perbuatan atau peristiwa hukum. Pasal 14 Kompilasi Hukum Islam menjelaskan mengenai rukun perkawinan, yaitu: untuk melaksanakan perkawinan harus ada: Calon suami; Calon isteri; Wali nikah; Dua orang saksi dan; Ijab dan Kabul.

Menurut hukum Islam, perkawinan dinyatakan sah apabila rukun dan syarat-syarat perkawinan telah terpenuhi serta tidak melanggar larangan-larangan perkawinan. Rukun perkawinan menurut hukum Islam adalah adanya calon mempelai laki-laki, calon mempelai perempuan, wali nikah sesuai urutan yang berhak menikahkan, disaksikan setidaknya dua orang laki-laki atau empat orang perempuan, dan ijab kabul. Sedangkan syarat sahnya perkawinan, menurut hukum Islam adalah adanya calon mempelai laki-laki dan perempuan, calon mempelai laki-laki dan perempuan harus sudah baligh (berakal), adanya persetujuan antara calon mempelai laki-laki dan perempuan, yang tidak ada paksaan dari manapun, perempuan yang hendak dinikahi oleh laki-laki bukan termasuk perempuan yang haram untuk dinikahinya.

Sahnya suatu perkawinan sangat penting untuk menentukan sejak kapan hubungan kelamin antara laki-laki dan perempuan tersebut dihalalkan dan bebas dari dosa perzinaan. Perkawinan dalam agama Islam menjelaskan mengenai sahnya perkawinan adalah pada saat selesainya akad nikah yang diucapkan oleh kedua belah pihak yaitu antara wali nikah dari pihak perempuan dengan mempelai pria. Perkawinan merupakan suatu ikatan yang berlaku seumur hidup bagi suami 
istri yang kawin, oleh karena itu sangat dibutuhkan persetujuan dari mereka yang melangsungkan perkawinan itu. ${ }^{9}$

Pada perkawinan tersebut terdapat mempelai laki-laki dan perempuan yang sudah baligh, perkawinan tidak ada paksaan dari pihak manapun dan perkawinan tersebut dihadiri oleh setidaknya dua orang saksi serta adanya wali nikah. Mempelai perempuan merupakan perempuan yang tidak terhalang oleh larangan perkawinan dan perkawinan dilaksanakan setelah masa iddah perempuan dengan mantan suami habis. Akan tetapi, permasalahannya adalah perkawinan tersebut di langsungkan atas kesepakatan bahwa perkawinan akan dilangsungkan untuk sementara waktu saja, serta para pihak yang melangsungkan perkawinan kuli kawin harus memenuhi isi kesepakatan yang dibuat. Perkawinan tersebut juga dilangsungkan dalam waktu yang singkat agar menghalalkan rujuknya Ayi kepada Sumiyati.

Praktek kuli kawin yang terjadi di Desa Pamanukan Hilir Kabupaten Subang bertujuan menghalalkan perempuan yang sudah ditalak 3 (tiga) oleh mantan suaminya agar bisa rujuk kembali dengan mantan suaminya. Perkawinan semacam ini timbul karena adanya larangan perempuan yang telah ditalak tiga oleh suaminya, baik secara bertahap maupun sekaligus untuk kawin lagi dengan mantan suaminya tersebut, sebagaimana disebutkan dalam Al-Qur'an Surat AlBaqarah ayat 230 yang artinya:

Kemudian jika si suami mentalaknya (sesudah talak yang kedua), maka perempuan itu tidak lagi halal baginya hingga dia kawin dengan suami yang lain, kemudian jika suami yang lain itu menceraikannya, maka tidak ada dosa bagi keduanya (bekas suami pertama dan istri) untuk kawin kembali jika keduanya berpendapat akan menjalankan hukum-hukum Allah, diterangkan-Nya kepada kaum yang (mau) mengerti”.

Mohd. Idris Ramulyo memberikan pandangan bahwa perkawinan itu merupakan suatu perjanjian bila dilihat dari segi hukum, sebagaimana ditegaskan dalam Al-Qur'an Surat An-Nisa ayat 21 yang artinya perkawinan adalah "perjanjian yang sangat kuat" yang disebut dengan istilah "miitsaqaan gholiidhan", selain itu sebagai alasan untuk menyatakan bahwa perkawinan itu merupakan suatu perjanjian ialah karena adanya untuk mengadakan perkawinan telah diatur terlebih dahulu, yaitu dengan adanya akad nikah dan rukun atau syarat tertentu dengan cara menguraikan atau memutuskan ikatan perkawinan juga telah diatur sebelumnya yaitu dengan prosedur talak, kemungkinan fasakh, syiqaq, dan sebagainya. ${ }^{10}$

Pelaku kuli kawin menghilangkan arti dari ikatan perkawinan yang seharusnya merupakan suatu ikatan janji yang kokoh sebagaimana dalam alQur'an disebut dengan "mitsaqaan ghalidza". Ikatan perkawinan mengarisyaratkan bahwa perkawinan merupakan perjanjian serius antara

${ }^{9}$ Lili Rasjidi, Hukum Perkawinan dan Perceraian di Malaysia dan Indonesia, Bandung: Alumni, 1982.

${ }^{10}$ Ibid, hlm.2. 
mempelai pria (suami) dan mempelai perempuan (istri) yang tidak boleh dipermainkan atau ditujukan hanya untuk sementara waktu.

\section{Keabsahan Perkawinan Kuli Kawin di Desa Pamanukan Hilir Kecamatan Pamanukan Kabupaten Subang}

Keabsahan perkawinan kuli kawin di Desa Pamanukan Hilir Kecamatan Pamanukan Kabupaten Subang adalah perkawinan yang tidak sah menurut hukum islam dan juga undang-undang perkawinan karena perkawinan tersebut tidak sah menurut agama Islam. Akibat hukum dari perkawinan kuli kawin di Desa Pamanukan Hilir Kabupaten Subang ditinjau dari Undang-undang Nomor 1 Tahun 1974 tentang Perkawinan dan Hukum Islam.

Hukum positif di Indonesia menyebutkan bahwa perkawinan tidak hanya sebagai suatu perbuatan hukum yang menimbulkan akibat-akibat hukum, tapi juga merupakan perbuatan keagamaan, sehingga sah atau tidaknya suatu perkawinan ditentukan menurut hukum agama dan kepercayaan masing-masing orang yang melangsukan perkawinan. Hal ini berbeda dengan konsep perkawinan menurut Hukum Perdata Barat yang hanya memandang perkawinan hanya sebagai perbuatan keperdataan belaka.

Status keabsahan suatu perkawinan sangat penting untuk menentukan akibat-akibat hukum dari perkawinan tersebut, diantaranya hak dan kewajiban suami istri, harta benda perkawinan, status kedudukan anak, dan lain-lain. Sebagai perkawinan yang tidak sah, perkawinan kuli kawin tidak memiliki akibat hukum sebagai mana perkawinan pada umumnya. Terlebih perkawinan ini dilakukan tanpa dicatatkan ke instansi yang berwenang sehingga perkawinan ini tidak dapat diakui oleh Negara. Oleh karena itu, perkawinan kuli kawin statusnya sama dengan perkawinan di bawah tangan.

Perkawinan kuli kawin sering disalah artikan oleh sebagian orang, termasuk oleh para mantan suami. Banyak orang beranggapan cukup dengan dilangsungkannya perkawinan antara perempuan yang telah ditalak tiga dengan laki-laki lain maka setelah perempuan tersebut bercerai dan telah habis masa iddahnya, dia dianggap sudah boleh kawin lagi dengan mantan suami pertamanya. Tetapi mereka yang melakukan perkawinan kuli kawin biasanya tidak memikirkan bahwa perkawinan untuk menghalalkan perempuan yang telah ditalak 3 (tiga) untuk kembali kepada mantan suaminya mempunyai syarat-syarat tertentu.

Persyaratan halalnya suami pertama kepada mantan isteri yang telah ditalak 3 (tiga), yaitu: perkawinan kuli kawin tidak boleh dibatasi waktunya, perkawinan tersebut berjalan secara wajar atau alamiah tanpa ada rekayasa, suami kedua dan perempuan telah melakukan hubungan kelamin, telah dicerai oleh suami keduanya dan telah habis pula masa iddahnya. Apabila syarat-syarat tersebut telah terpenuhi semua barulah suami pertama halal untuk rujuki dengan mantan isterinya. Tapi dalam praktiknya, suami pertama dan mantan isterinya tidak mengindahkan persyaratan bahwa perkawinan kuli kawin tidak boleh dilakukan dengan rekayasa melainkan harus berjalan secara alamiah.

Pencatatan perkawinan walaupun hanya merupakan tindakan administratif saja bukan sebagai salah satu faktor penentu sahnya suatu perkawinan, namun pencatatan perkawinan menjadi hal yang penting untuk memberikan kepastian 
hukum terkait status dan kedudukan suatu perkawinan yang nantinya juga akan berpengaruh pada akibat hukum yang ditimbulkan dari perkawinan tersebut.

Dilakukan pencatatan perkawinan bertujuan untuk menambah kekuatan pembuktian perkawinan karena dengan mencatatkan perkawinan, negara akan mengeluarkan akta otentik sehingga menjadikan perkawinan bersangkutan tidak dapat dipungkiri oleh siapapun, dan menjadi bukti bahwa Negara telah mengakui keabsahan perkawinan tersebut.

Pencatatan secara administratif yang dilakukan Negara dimaksudkan agar perkawinan sebagai perbuatan hukum penting dalam kehidupan yang dilakukan oleh yang bersangkutan dikemudian hari dapat dibuktikan dengan bukti yang sempurna dengan suatu akta otentik, sehingga perlindungan dan pelayanan oleh Negara terkait dengan hak-hak yang timbul dari suatu perkawinan dapat terjamin apabila para pihak tidak memenuhi kewajibannya. Artinya, dengan dimilikinya bukti otentik akta perkawinan, hak-hak yang timbul sebagai akibat perkawinan dapat terlindungi dan terlayani dengan baik oleh Negara.

Perkawinan di bawah tangan mengakibatkan hilang atau gugurnya akibatakibat hukum yang seharusnya timbul dari suatu perkawinan yang sah terutama akibat hukum seperti hak dan kewajiban suami istri dan status kedudukan anak. Perkawinan kuli kawin sebagai salah satu bentuk perkawinan di bawah tangan akan mengakibatkan laki-laki dan perempuan yang melangsungkan perkawinan akan kehilangan hak dan kewajibannya sebagai suami istri menurut Undangundang. Jika salah satu pihak tidak memenuhi kewajibannya maka pihak lain tidak bisa menuntut pemenuhan haknya tersebut ke pengadilan karena perkawinan mereka tidak diakui atau dianggap tidak pernah ada menurut hukum Negara.

Pihak perempuan bisa kehilangan atau tidak mendapat hak-haknya secara penuh yang seharusnya timbul dari suatu perkawinan yang sah terutama akibat hukum yang berhubungan dari segi keperdataan. Misalnya, hak untuk mendapatkan nafkah lahir dan batin, hak nafkah, serta hak penghidupan atas anak. Bahkan setelah bercerai, suami tidak wajib memberikan biaya penghidupan kepada mantan isterinya selama masa iddah dan isteri akan kehilangan haknya untuk menuntut nafkah kepada suaminya tersebut.

Tidak sahnya perkawinan kuli kawin menurut hukum Negara dan agama juga akan berdampak terhadap status dan kedudukan anak yang mungkin lahir dari perkawinan tersebut. Anak yang lahir dari perkawinan kuli kawin tidak akan mendapat status sebagai anak sah. Sebab, menurut Pasal 42 Undang-undang Nomor Tahun 1974 tentang Perkawinan, anak yang bisa digolongkan sebagai anak sah hanyalah anak yang dilahirkan dalam atau sebagai akibat perkawinan yang sah. Sedangkan status perkawinan kuli kawin adalah perkawinan yang tidak sah sehingga anak yang lahir dari perkawinan tersebut akan disebut sebagai anak luar kawin.

Anak-anak yang dilahirkan di luar perkawinan yang sah atau dari perkawinan yang tidak dicatat selain dianggap sebagai anak tidak sah, anak juga hanya akan memiliki hubungan keperdataan dengan ibu dan keluarga ibunya sebagaimana ditegaskan dalam Pasal 43 ayat (1) Undang-undang Perkawinan bahwa: "Anak yang dilahirkan di luar perkawinan hanya mempunyai hubungan perdata dengan ibunya dan keluarga ibunya." 
Status anak yang dilahirkan sebagai anak tidak sah, menjadi anak kehilangan hubungan keperdataan dengan ayahnya. Bahkan, di dalam akte kelahirannya pun statusnya dianggap sebagai anak luar kawin, sehingga hanya dicantumkan nama ibu yang melahirkannya. Keterangan berupa status sebagai anak luar kawin dan tidak tercantumnya nama ayah tentu akan berdampak secara sosial dan psikologis bagi anak. Hal yang juga akan sangat merugikan si anak adalah anak tidak berhak atas biaya kehidupan, pendidikan, nafkah dan warisan dari ayahnya.

\section{Penutup}

Berdasarkan uraian yang telah dikemukakan pada bab-bab sebelumnya, dapat disimpulkan sebagai berikut:

1. Status perkawinan kuli kawin yang dilakukan oleh Rukiyat dan Sumiyati serta Kamal Muhtar dan Titi Sadi merupakan perkawinan yang tidak sah karena bertujuan menghalalkan perempuan yang sudah ditalak tiga agar dapat rujuk kembali dengan mantan suaminya bukan dilakukan untuk menjalankan sunah Rasul untuk membentuk suatu ikatan yang akan bertahan selamanya. Karena tidak sah menurut hukum agama maka perkawinan tersebut bertentangan dengan ketentuan Pasal 2 ayat (1) Undang-Undang Nomor 1 Tahun 1974 tentang Perkawinan yang menyebutkan bahwa perkawinan sah, apabila dilakukan menurut hukum masing-masing agama dan kepercayaannya itu, serta bagi masyarakat Islam setiap peristiwa perkawinan harus dicatatkan berdasarkan ketentuan Pasal 5 ayat (1) Kompilasi Hukum Islam.

2. Akibat hukum dari perkawinan kuli kawin ini berdasarkan Hukum Islam adalah haram hukumnya karena perkawinan tersebut melanggar tujuan pernikahan sebagai suatu ikatan suci atau mitssaqan ghalidzan yang tercantum dalam Pasal 2 Kompilasi Hukum Islam, serta melanggar prinsip perkawinan yang tercantum dalam Pasal 1 Undang-Undang Nomor 1 Tahun 1974 tentang Perkawinan yaitu perkawinan kekal berdasarkan Ketuhanan Yang Maha Esa.

\section{DAFTAR PUSTAKA}

\section{A. Buku}

Ahmad Azhar Bashir, 1987, "Hukum Perkawinan Menurut Agama Islam”, BPFH Uli, Yogyakarta.

Ahmad Kuzari, 1995, “Nikah Sebagai Perikatan”, Raja Grafindo, Jakarta.

Ahmad Warson, 1997, "Kamus Al-Munawir Arab-Indonesia Terlengkap", Pustaka Progresif, Yogyakarta.

Dewan Redaksi Ensklopedia Islam, 1994, "Ensklopedia Islam”, PT. Ikhtiar Baru Van Hoeve, Jakarta.

H.A. Malik Madaniy, 2015, "Nikah Sirri Dalam Perspektif Hukum islam", Makalah Disampaikan dalam rangka seminar nikah sirri yang diselenggarakan oeh DKM Masjid Universitas Padjadjaran, Bandung. 
Hilman Hadikusuma, 2011, "Hukum Perkawinan Indonesia Menurut UndangUndang, Hukum Adat, Hukum Agama”, Mandar Maju, Bandung.

Lili Rasjidi, 1982, "Hukum Perkawinan dan Perceraian di Malaysia dan Indonesia", Alumni, Jakarta.

Luqman Haqani, 2014, "Prahara Rumah Tangga", Pusaka Ulumuddin, Bandung.

M Syaifuddin, Sri Turatmiyah, Annalisa Yahanan, 2014, "Hukum Perceraian”, Jakarta, Sinar Grafika,

Mardani, 2011, "Hukum Perkawinan Islam Di Dunia Modern”, Graha Ilmu, Yogyakarta.

Moh Saifulloh Al Aziz, 2005, "Fiqh Islam Lengkap", Terbit Terang, Surabaya.

Mohammad Thalib, Sayyid Sabiq, 1980, "Fikih Sunnah", Jilid 6, Cet 15, PT. Alma'arif, Bandung.

Mohd Idris Ramulyo, 2004, "Hukum Perkawinan Islam", PT. Bumi Aksara, Jakarta.

Muhammad Amin Summa, 2005, "Hukum Keluarga Islam di Dunia Islam”, PT Raja Grafindo Persada, Jakarta.

Muhammad Syaifuddin, dkk, 2014, “Hukum Perceraian” cet. 2, Sinar Grafika Jakarta.

Mukti Arto, "Masalah Pencatatan Perkawinan dan Sahnya Perkawinan". Mimbar Hukum, olume 26, Mei-Juni 1996, Jogyakarta.

Neng Djubaedah, dkk, 2005, "Hukum Perkawinan Islam di Indonesia", Hecca Mitra Utama, Jakarta.

Neng Djubaedah, 2010, "Pencatatan Perkawinan Dan Perkawinan Tidak Dicatat Menurut Hukum Tertulis di Indonesia dan Hukum Islam”, Sinar Grafika, Jakarta.

Prof. DR. H. Moch. Isnaeni, S.H., MS., 2009, "Hukum Perkawinan Indonesia", Refika Aditama, Bandung.

R. Abdul Djamali, 2002, "Hukum Islam", Mandar Maju, Bandung.

Ronny Hantjo Soemitro, 1990, "Penelitian Hukum dan Jurimateri", Cet ke 4, Thaila Indonesia, Jakarta.

Soemiyati, 1982, "Hukum Perkawinan Islam dan Undang-undang Perkawinan", Liberty, Yogyakarta.

Sulaiman Rasyid,1954, "Fiqh Islam”, Attahiriyah, Jakarta.

Sution Usman Adji, 1989, "Kawin Lari dan Kawin Antar Agama”, cet. 1, Liberty, Yogyakarta.

Titik Triwulan Tutik, 2011, "Hukum Perdata Dalam Sistem Hukum Nasional", Kencana, Jakarta.

Van Apeldoorn, 1983, "Pengantar Ilmu Hukum", cet ke-20, Pradnya Paramita, Jakarta.

Wahbah al-Zuhaili, 1989, "al-Fiqih al-Islam wa Adillatuhu”, Dar al-fikr, Damaskus.

Wirjono Prodjodikoro, 1990, "Hukum Perkawinan Indonesia”, Bulan Bintang, Jakarta.

B. Peraturan Perundang-undangan

Undang-Undang Dasar Negara Republik Indonesia Tahun 1945 
Kitab Undang-Undang Hukum Perdata

Undang-Undang Nomor 1 Tahun 1974 tentang Perkawinan

Peraturan Pemerintah Nomor 9 Tahun 1975 tentang Pelaksanaan Undang-Undang Nomor 1 Tahun 1974 tentang Perkawinan.

Instruksi presiden Nomor 1 Tahun 1991 tentang Kompilasi Hukum Islam 